\title{
Determinants of Economic Value Added (EVA) in Chinese Listed Banks
}

\section{Determinants of Economic Value Added (EVA) in Chinese Listed Banks}

\author{
Jie Zhang ${ }^{\text {a }}$
}

Ahmed Aboud ${ }^{b, *}$

${ }^{a}$ University of Southampton Business School, Southampton, U.K

${ }^{\mathrm{b}}$ Portsmouth Business School, University of Portsmouth, U.K

* Corresponding Author

\section{Structured Abstract}

Purpose - This paper examines the determinants of the EVA performance evaluation model for the Chinese banking industry. We investigate the impact of six bank-specific factors and corporate governance factors on financial performance.

Design/methodology/approach - the authors use the ordinary least square regression to examine the determinants of the EVA performance evaluation model for the Chinese banking industry. Our findings are generally robust to alternative proxies of performance. 
Findings - The empirical results indicate that credit risk, operational efficiency and the degree of innovation are positively related to banks' EVA while capital management has a negative impact on it. In addition, although board size and independent directors are not related to the bank's EVA, from the perspective of the traditional performance evaluation indicators, executive compensation has a positive impact on the bank's profitability.

Research limitations/implications - This paper has some limitations. Firstly, due to the large number of adjustments to accounting items are required in the application of EVA when evaluating business performance, some items of EVA model in this paper have been simplified, which may cause the bank's EVA value to deviate slightly from the actual situation. Moreover, the sample includes only listed banks, so our results cannot generalize to non-listed banks, such as some small and medium-sized commercial banks.

Originality/value - This paper contributes to the limited body of literature concerning the use and the determinants of EVA in emerging markets. We construct an EVA model which is suitable for China's banks and report comprehensive evidence on the drivers of EVA as a measurement tool.

Keywords: Bank Performance, EVA, Corporate Governance, Bank Specific Factors, China, Innovation.

Article Type: Research paper

\section{Introduction}

Previous research has indicated that the application of EVA varies substantially across organizations and that variations are due to differences in the regulatory environments and industry specific characteristics (Worthington \& West 2001; Chiwamit et al., 2017: Chiwamit et al., 2014; Burkert and Lueg, 2013; McLaren et al., 2016). Banks, as a special industry, are the mainstay of the market economic activities and the modern financial system, occupying an important position in a country's financial and even economic systems. Particularly, in order to adapt to the fast-paced developing in 
China's economy and the increasingly fierce competition in the external market, the Chinese banking industry has implemented a series of reform measures since 1997 (Sufian, 2009).

In pre-1978 era, China did not have a banking system in the modern sense. After experiencing the stage of the two-tiered banking system and the stage of state-owned commercial banks, the Chinese banking industry has gradually transitioned to the stage of the state-owned commercial banks (Heffernan and Fu, 2010). Since 2000, China has begun to encourage and promote the reorganization and listing of China's state-owned commercial banks and expand the scale to meet the challenges brought by the full opening of the financial industry after China's accession to the world trade organization. By the end of 2010, the four state-owned commercial banks successively completed the public offering of shareholding reforms, the business cooperation between joint-stock banks continued to deepen and the rural credit cooperatives became city commercial banks (CBRC, 2016).

With the banking reforms, China's banking industry has shifted from a traditional expansion model focusing on scale and speed to a profit-oriented management focusing on capital constraints, risk control, and asset quality. Maximizing value as the goal of bank management has become the consensus of shareholders, bank managers and operators (Heffernan and $\mathrm{Fu}, 2010$ ). However, in practice, the China's banks still follow a performance evaluation system based on indicators such as total return on assets (ROA) and return on equity (ROE). Since the business risk and capital cost are not considered, this traditional performance evaluation system deviates from the banks' business objectives of maximizing shareholders' interests and corporate value. Therefore, how to construct a reasonable bank performance evaluation system to guide the behaviour of bank managers and operators has become an important research topic internationally and in China's banking industry.

The Economic Value Added (EVA) could make up for the shortcomings of traditional performance evaluation indicators and meet the management objectives of China's banking industry on maximizing shareholder value. EVA is considered as one of the innovations with a long-standing pedigree in conventional management accounting 
thought, but also assuming wider societal relevance (Chiwamit et al., 2014, p145). EVA, presented by Stern Stewart in 1982, measures the added value of corporate wealth. It has been registered to form a financial management system, incentive system and decision-making mechanism led by the concept of economic value added (Stewart 1991). Stewart (1991) defined EVA as "the difference between the profits each unit derives from its operations (NOPAT) and the charge for capital each unit incurs through the use of its credit line". Unlike traditional performance evaluation indicators such as ROA and ROE, EVA examines the company's residual profit, that is, the net value after deducting the direct cost of borrowed capital and the indirect cost of equity capital (Sabol and Sverer, 2017).

This is consistent with the essence of economic profit. Moreover, EVA redefines the profit of the company from the perspective of shareholders, considering the cost of all capital invested by the company (including equity capital), which is almost the same as the requirement of maximizing shareholders' wealth. Furthermore, in the calculation of EVA, the company also needs to adjust the financial information that the business managers may manipulate, which makes the EVA indicators closer to the real performance of the enterprise (Mamun and Mansor, 2012). In addition, the application of EVA could establish an effective incentive compensation system, linking operating performance with EVA to alleviate agency problem, and encourage managers to pay full attention to the company's capital appreciation and long-term economic benefits (Worthington \& West 2001; Fatimi et al, 2003).Thus, we argue that the alignment of managerial interests and incentives with the preferences of shareholders can be potentially achieved through the use of EVA (Sabol and Sverer, 2017; Chiwamit et al., 2014; Bouwens and Spekle 2007).

In the practical application of EVA, compared with some internationally renowned companies such as Coca-Cola, IKEA, Wal-Mart, the application of EVA in the banking industry started relatively late. In 1994, Centaur Bank from the United States first introduced EVA to its performance evaluation system, and then internationally renowned banks including Citibank also joined the ranks of EVA users. In the Chinese banking industry, China Construction Bank (CCB) introduced the EVA indicator for the first time in 2002. Starting with the goal of maximizing bank value, CCB affirmed the important role of EVA in the performance evaluation of commercial banks. 
Subsequently, other large state-owned commercial banks and Joint-stock commercial bank such as Industrial Bank (IB) also began to try to introduce EVA into their performance management system. Therefore, the introduction of EVA into the banking industry is probably a general trend in the future.

While previous studies addressed the applications and the effectiveness of EVA, the current study aims to examine the determinants of EVA in the Chinese banking industry (Uyemura et al, 1996; Fraker, 2006; Franco and Philip, 2007; Gabriela et al, 2009; Soral and Bhanawat, 2009; Worthington \& West 2001). Particularly, we examine the impact of a set of bank specific factors (liquidity and credit risks, executive compensation, operational efficiency, and capital management) on bank performance. Furthermore, we address the effects of innovation and corporate governance characteristics (board size, independence and compensation) on the performance of Chinese banks.

Using a sample from 2012 to 2017, our study finds that credit risk (LLR), operational efficiency (C/B), capital management (CAR) and the degree of innovation (NIIR) are affecting the EVA value of China's listed banks. These findings suggest that improving the operation efficiency and the degree of innovation, ensuring a certain level of credit risk and a certain level of capital adequacy ratio could help improve the bank's operating performance. In contrast, we find no evidence that corporate governance characteristic (Board Size and Proportion of independent directors) have significant impact on EVA value of China's listed banks. Although board Size and proportion of independent directors are not related to the bank's EVA, executive compensation has a positive impact on the bank's profitability. These results imply that executive compensation schemes can help alleviate the agency problem in publicly listed banks and thus maximize shareholder value (Omoregie and Kelikume, 2017; Malmi and Ikäheimo 2003).

This paper contributes to the existing literature in different ways. Firstly, there is no uniform standard for the EVA calculation formula of the banking industry (Uyemura et al, 1996; Fraker, 2006; Gabriela et al, 2009; Soral and Bhanawat, 2009), thus this paper attempted to construct an EVA model which is suitable for China's banks. Secondly, although existing literature addressed the determinants of bank's profitability, most 
studies still use the traditional accounting indicators such as ROA and ROE to measure the bank's profitability (Bennaceur and Goaied, 2008; Sufian and Chong, 2008; Sufian, 2009; Ali et al, 2011; Aladwan, 2015; Petria et al, 2015).Our study is one of the few studies that empirically examined the key factors affecting the creation of banks value under the condition of EVA as a measurement tool (Heffernan and Fu, 2010). Moreover, we provide comprehensive evidence on the drivers of EVA as a measurement tool. While most research is still limited to a number of bank-specific factors (Bennaceur and Goaied, 2008; Sufian and Chong, 2008; Sufian, 2009; Heffernan and Fu, 2010; Ali et al, 2011; Aladwan, 2015; Petria et al, 2015), our study addresses the impact of executive compensation, degree of innovation, board size and independence on EVA as a measurement of bank performance. By doing so, our study provides insights about new factors that may affect the creation of banks value under the condition of EVA as a measurement tool, and thus guide the banks to allocate resources to places that create more value.

The rest of the paper is organized as follows. Section 2 presents the basic concepts, features and construction of EVA model in the banking sector. Literature review and hypotheses development are outlined in Section 3. Section 4 discusses the data and method. Section 5 presents the results while Section 7 concludes.

\section{EVA as a Measure of Performance}

\subsection{Basic Concepts of EVA Evaluation Indicators}

Economic Value Added (EVA) refers to the difference between the net profit after tax of the enterprise and the total cost of capital invested in the operation of the enterprise during a certain period (Sabol and Sverer, 2017). It is not a new concept but an extension of residual income and economic profit, which represents the ability of enterprise value creation (Sharma and Kumar, 2010). When the company's post-tax net operating profit exceeds the total capital cost of the investment, the EVA is positive, and the value created by the company brings about an increase in the shareholder's wealth (Sabol and Sverer, 2017). Conversely, if the EVA is negative, the company's operating income is not enough to cover all the capital costs, including debt capital and equity capital costs, resulting in a reduction in shareholder wealth (Mamun and Mansor, 2012). The formula for EVA can be expressed as: 


\section{$\mathrm{EVA}=\mathrm{NOPAT}-\mathrm{WACC} \times \mathrm{TC}$}

Thus, EVA is mainly composed of three elements that is NOPAT, TC and WACC. NOPAT indicates the net profit after tax operation of the enterprise, that is, the sum of net profit after tax and interest expense, which is the profitability of the company after the capital structure is removed (Sharma and Kumar, 2010). All calculation factors of net operating profit after tax could be obtained from the financial statements disclosed by the company. Specifically, the company's operating income is the remaining part which deducted from the costs and expenses consumed in the production and operation process as well as the income tax (Mamun and Mansor, 2012). Thus, NOPAT could be understood as the real profitability of the company's assets. TC represents the total investment capital of the company, including debt capital and equity capital (Sabol and Sverer, 2017). Among them, debt capital refers to short-term loans and long-term loans provided by creditors other than commercial liabilities such as accounts payable, notes payable and other payables (Jakub et al, 2015). The cost of equity consists of common stock and minority shareholders' equity. Weighted average cost of capital (WACC) is the average unit cost calculated from the weight of the debt cost and the cost of equity in the total capital structure. The critical problem in calculating WACC is the estimation of the cost of equity capital (Jakub et al, 2015). The most widely used is the Capital Asset Pricing Model (CAMP) (Sabol and Sverer, 2017).

In addition, in order to further ensure the reliability of EVA calculations, certain adjustments must be made to specific accounting items in the income statement and balance sheet (Sharma and Kumar, 2010). Since the EVA indicator was not specifically pointed to a certain industry when it was proposed, Stern Company gave a total of 160 accounting adjustment items for the specific measurement of the EVA model when they first introduced the EVA evaluation system (Mamun and Mansor, 2012). They pointed out that when applying the EVA indicator, the company needs to choose these accounting adjustments according to the actual position of the company. In general, the required adjustments in the optimal EVA calculation formula should be within 15 items (Mamun and Mansor, 2012). Therefore, it is one of the contributions of this paper to select the adjustments according to the characteristics of the banking industry, as will be discussed in section 2.2 


\subsection{Features of the EVA Model in the Banking Sector}

Banks, unlike ordinary industrial enterprises, mainly operate in the form of currency, while providing financial products and services ( $\mathrm{Li}$ and Guan, 2009). Their capital structure, profit-making methods and risks are special. Therefore, in the process of applying the EVA analysis method, the banking industry needs to pay attention to the accounting adjustment of the basic formula of EVA according to the particularity of the banking industry (Shreenivasan and Vaijayanthi, 2011).

Compared with enterprises in the other industries, it could be found that there is a big difference between banks and the general enterprises in their capital structure, which is a high-debt operation (Shreenivasan and Vaijayanthi, 2011). Banks only consider the cost of equity capital, rather than dividing capital into debt capital and equity capital according to the general practice. This is because the bank's main business is to absorb deposits and issue loans, and its liabilities are mainly derived from the deposits of corporate and residents (Gabriela et al, 2009). According to the requirements of the Basel Concordat, the capital adequacy ratio of commercial banks need to reach $8 \%$, which means that the asset-liability ratio of banks would reach $90 \%$ (Li and Guan, 2009). In order to generate higher income, banks usually keep their capital adequacy ratio above $8 \%$ to meet the standard, thus banks generally have high debt ratios.

From the perspective of profit-making methods, the main commodity of banks is capital and their main form of profit is realized by issuing loans to enterprises that need funds (Li and Guan, 2009). In contrast, the profit-making method of general enterprises is to sell goods or provide processing services to obtain profits. Therefore, the interest paid by the banking is both a cost of debt and a part of operating expenses (Shreenivasan and Vaijayanthi, 2011). Due to the existence of statutory capital, the amount of interest expenses of banks is relatively large. Thus, adding the interest expense back to the net profit will lead to overvalued cost of capital.

Moreover, the risks that commercial banks bear have certain specialties. Different from the industrial enterprises with cash as the king, the key to the survival of banks lies in the control of risks, which means the core of financial management for banks is risk management (Shreenivasan and Vaijayanthi, 2011). This is because the operation of the 
banking industry is closely related to the country level financial system; when the national economy is in crisis, banks generally would be affected (Li and Guan, 2009). Similarly, if banks have risks for various reasons, they would also affect the development of the entire country's economy that why banking industry is heavily regulated. Therefore, the important role of banking capital is to resist risks, and the scale of capital should be matched with the anticipated risks. This is also an important reason for the difference between EVA measurement in the banks and industrial enterprises.

\subsection{Construction of EVA Model in the Banking Sector}

According to the characteristics of the banks, it is necessary to make some special adjustments when constructing the EVA Model in the Banking Sector.The first step in calculating EVA is to adjust the company's net profit to produce its NOPAT (Gabriela et al, 2009). According to the previous literature, the adjustment of NOPAT in the banking sector could be divided into four parts: Interest expense, provision for loan loss, non-recurring events and deferred taxes.

As mentioned in the last section, due to the particularity of the banking industry, interest charges are included in the NOPAT. According to Gabriela et al. (2009) and Shreenivasan and Vaijayanthi (2011), the definition of net operating profit after tax in the EVA calculation formula reflects the portion of after-tax profit plus interest expense. But for the bank, the deposit business itself is a kind of debt, and the interest generated by the loan business is its main business income. Therefore, in the adjustment of net operating profit after tax, interest income is not adjusted.

Provision for loan losses is one of the most common adjustments for a bank. (Gabriela et al, 2009). Under GAAP, banks need to increase its loan loss reserve with an equal amount expensed as provision for loan losses, aiming to write off a portion of each loan as soon as possible (Fraker, 2006). The reserve includes estimated loss adjustments for existing loans and estimates of future loan losses associated with new loans (Uyemura et al, 1996). This accounting rule would cause two adverse effects. On the one hand, the provision for loan losses is only on the principle of prudence and banks have not actually suffered losses. It is easy to widen the gap between accounting profit and cash 
flow, as well as underestimate the actual profitability and the actual amount of total assets (Fraker, 2006). On the other hand, the provision for loan losses has a certain degree of discretion. Thus, the bank's managers have an opportunity to use this discretion to manipulate the measurement and the reporting of the provisions to meets the manager's expected demand (Uyemura et al, 1996). Therefore, when calculating the EVA index of a commercial bank, the amount of change in provision for loan losses should be subtracted from the after-tax profit.

Non-recurring events refer to the events, which are not related to bank operations, and the resulting gains and losses are contingent, such as debt restructuring gains and losses, sales of fixed assets and intangible assets and government subsidies. Uyemura et al (1996) stated that the main non-recurring event of the banking industry in recent years is restructuring costs. Due to such expenses might represent a divestment, it should not be considered as a reduction in operating profit and the adjustment should be made after tax. These non-recurring income or losses are generally recorded in non-operating income and non-operating expenses (Fraker, 2006). The bank's non-operating income and expenses do not reflect the true business conditions of the bank. Therefore, nonoperating income and expenses should be excluded when calculate the NOPAT of banks. Deferred income tax arises from differences in the tax bases provided for by the tax law and the tax bases set out in the accounting standards. Deferred tax assets and liabilities are expenses that should be deducted or paid in the future (Uyemura et al, 1996). Thus, another adjustment to EVA model is to add the deferred income tax back to the NOPAT of banks. Particularly, consistent with Fraker, (2006) we added deferred income tax liabilities and minus deferred income tax assets

According to the above explanation of adjustments, the adjusted formula of NOPAT is as follow:

NOPAT $=$ Net profit + Change in Provision for loan losses $\times(1-$ Income tax rate $)-($ Nonoperating income - Non-operating expenses $) \times(1$ - Income tax rate $)+$ Change in Deferred income tax liabilities - Change in Deferred income tax assets

The total capital (TC) refers to the book value of all capital operated by the company, 
including debt capital and equity capital (EC). Due to the particularity of the bank's capital structure mentioned above, most of the debt capital of banks is reflected in the statement of the banking industry as an operating liability, and its interest expenses constitute a declining income (Gabriela et al, 2009). In addition, the regulatory authorities have strict limits on the minimum capital adequacy ratio according to Basel III, thus debt capital only accounts for a small proportion of total capital in the banking sector ( $\mathrm{Li}$ and Guan, 2009). If the capital is calculated based on the method of the general enterprise, the capital cost of the bank will be overestimated. Therefore, the "total equity" is often based on its equity capital figure when calculating the bank's EVA (Fraker, 2006).

According to Uyemura et al., (1996), the total capital for banks could be summarized from the adjustments discussed above for NOPAT, which contains three components: loan loss reserves (after taxes), other net deferred tax credits and Non-recurring events (after taxes). According to the above explanation of adjustments, the adjusted formula of TC is as follow:

$T C=$ Total equity capital + Reserve for NPLs $\times(1-$ Income tax rate $)-($ Non-operating income - Non-operating expenses $) \times(1$ - Income tax rate $)+$ Deferred income tax liabilities - Deferred income tax assets

The weighted average cost of capital (WACC) is the basic rate of return and opportunity cost required by corporate investors to invest in capital (TC), which is the price that companies must pay for using capital. Since the total capital only considers equity capital, only the capital cost rate needs to be calculated when calculating the WACC. Thus, we use capital asset pricing model (CAPM) to calculate the cost of capital (Fraker 2006), Gabriela et al., 2009, Soral and Baharat, 2009) for the calculation of the cost of capital, our paper uses capital asset pricing model (CAPM) to calculate the cost of capital.

\section{Literature Review and Hypotheses development}

Previous literature have examined the impact of bank-specific factors on banking performance in different countries (Sufian 2009; Heffernan and Fu 2010; Petria et al., 
2015; and Bennaceur and Goaied 2008; Sufian and Chong 2008; Ali et al., 2011). In addition to the bank specific factors, some studies have addressed the impact of corporate governance such as board size, independence and executive compensation on bank performance in recent years (Malmi and Ikäheimo 2003; Tulung and Ramdani 2018; Mariappan and Thyagarajan 2018; Fernandes et al., 2018). Therefore, this paper will extend the existing research by addressing the following nine determinants of profitability in the banking sector.

\subsection{Bank size}

The impact of bank size on bank profitability is controversial. On the one hand, banks have economies of scale (Sufian, 2009; Heffernan and Fu, 2010; Sufian and Chong, 2008). When the scale of bank size is expanded, the fixed costs will not increase due to the increase in the proportion of moving costs, so the unit product cost will decrease and the bank's profit rate will rise (Petria et al, 2015). Sufian (2009) found that a positive relationship between bank size and profitability in China. On the other hand, this expansion of bank size does not mean an affirmative increase in the level of bank performance (Heffernan and $\mathrm{Fu}, 2010$ ). The economies of scale for banks may reach a certain upper limit. This is because the increased diversification due to economies of scale might reduce the bank's credit risk and thus reduce returns (Sufian and Chong, 2008). Bureaucracy and other reasons, such as Chinese government interventions for the banking industry, may also have a negative impact on the bank's profitability (Petria et al, 2015). For instance, Sufian and Chong (2008) and Aladwan (2015) found that size is negatively correlated with the profitability of banks. However, some other studies found that there is no relation between bank size and profitability (Bennaceur and Goaied 2008; Heffernan and Fu 2010; Ali et al., 2011; Petria et al., 2015) Consistent with prior studies, the first hypothesis is as follows.

Hypothesis 1: There is a significantly positive relationship between bank size and the bank's EVA.

\subsection{Liquidity}

Liquidity risk refers to the risk that a bank cannot adapt to the decrease in liabilities or the increase in assets on the balance sheet, which is an important determinant of 
banking performance (Sufian, 2009). Comparing with other bank assets, the loans particularly the credit to resident and companies is risky and has more return (Sufian and Chong, 2008). Thus, it could be argued that liquidity is positively related to a bank's profitability. However, due to the high operational cost of loans such as screening and monitoring, the more loans might cause lower profitability of banks (Petria et al, 2015). Sufian (2009) and Sufian and Chong (2008) confirmed this view, and they found that the liquidity of the banking industry in China and the Philippines is negatively correlated with profitability. Heffernan and Fu (2010) found that the influence of liquidity is insignificant. Therefore, the second hypothesis is as follows.

Hypothesis 2: There is a significantly negative relationship between liquidity and the bank's EVA.

\subsection{Credit Risk}

Credit risk is related to the bank's ability of sustainable operation and profitability. For China's banking industry, the main business is still focused on deposits and loans, which means changes in credit risk could be reflected by the changes in the health of bank loan portfolios (Sufian and Chong, 2008). Non-performing loans refer to loans in which some of the borrowers' repayment ability has obviously become problematic, which means the borrowers cannot meet the repayment requirements relying on their normal operating income. Even if a bank has a guarantee, it cannot fully recover the cost, and there are even some cases where the loan cannot be recovered (Petria et al., 2015). Nonperforming loans as a part of the bank's assets but have seriously affected the bank's asset quality. Loan loss reserve refers to the provision for non-performing loans, which indicates the bank's asset quality and signal changes (Sufian, 2009). Higher provisions could indicate the possibility of loan losses in the future, but this may also show the bank's prudence and timeliness in estimating its non-performing loan (Heffernan and $\mathrm{Fu}, 2010$ ). Prior studies found that credit risk and bank's performance are negatively correlated (Sufian and Chong 2008; Ali et al., 2011; Petria et al., 2015), Therefore, the third hypothesis is as follows.

Hypothesis 3: There is a significantly negative relationship between credit risk and the bank's EVA. 


\subsection{Operational Efficiency}

Bank's operational efficiency (OE) refers to the management capacity of banks (Petria et al., 2015). In general, the higher the operational efficiency, the higher the profitability of the bank (Sufian, 2009). There are two main indicators for judging the capability of operational efficiency. One is the cost-to-income ratio, which reflects the percentage of bank operating costs as a percentage of income (Heffernan and Fu, 2010; Ali et al, 2011; Petria et al, 2015). The other is the ratio of overhead to total assets, which represents the total amount of wages and salaries of banks, as well as the cost of operating branch's facilities (Sufian, 2009; Sufian and Chong, 2008). However, no matter which indicator is used, it has a reverse relationship with the operational capability, that is, it has a reverse relationship with the performance of the bank. Previous studies conclude that the operational efficiency has a significantly positive relationship with bank's profitability (Sufian 2009, Heffernan and Fu 2010; Petria et al. 2015). Therefore, the forth hypothesis is as follows.

Hypothesis 4: There is significantly positive relationship between operational efficiency and the bank's EVA.

\subsection{Capital Management}

Capital adequacy ratio (CAR) has always been the focus of banks and regulators, but its impact on bank profitability is not clear. From a micro perspective, all kinds of banking institutions, such as central banks and commercial banks, must have certain ability to withstand risks, so that banks can minimize the banking crisis when the operating environment deteriorates ( $\mathrm{Li}$ and Guan, 2009). This ability to withstand risks is externally manifested in the bank's own capital, that is, the equity. The capital adequacy ratio reflects the ability of the banking industry to respond to liquidity risks and the solvency (Sufian and Chong, 2008). Therefore, in theory, the bank's capital adequacy ratio is positively related to its profitability (Sun et al, 2017). The empirical findings of Sufian (2009) and Sufian and Chong (2008) support this view. From another perspective, Petria et al. (2015) pointed out that capital replenishment also may led to a reduction in the number of funds available to banks, which might increase the cost of the bank's operations and lose more profitable investment opportunities. Moreover, the measurement of the EVA indicator is not only subject to the bank's profit level, but also 
emphasizes the hidden cost of the capital occupied. Heffernan and Fu (2010) used the EVA as an indicator of bank performance in their study and found a significant negative relation between capital adequacy and bank performance. Ali et al. (2011) used ROA and ROE as the indicators of bank performance and find similar results. Therefore, the fifth hypothesis is as follows.

Hypothesis 5: There is a significantly negative relationship between capital management and the bank's EVA.

\subsection{Degree of innovation}

The ability of innovation is important for the sustainable development of banks. In currently, the competition for the banking industry is becoming more and fiercer because their competitors are not only limited to banks, but also include various fund companies and other emerging financial companies (PWC, 2015). For example, the $\mathrm{Yu}$ Ebao, which launched by Alibaba and Tianhong Asset Management Limited Company, has made the Chinese banking industry feel a sense of crisis (PWC, 2015). Banks can no longer rely on the traditional deposit and loan business to make profits but need to innovate and develop its financial products. These financial innovations are reflected in the off-sheet account named "non-interest income" and the non-interest income ratio shows the degree of innovation for the banking sector (Sufian and Chong, 2008). Sufian and Chong (2008) found that the degree of innovation is positively associated with bank performance. Therefore, the sixth hypothesis is as follows.

Hypothesis 6: There is significant positive relationship between the degrees of innovation and the bank's EVA.

\subsection{Executive compensation}

Since the global financial crisis and the collapse of the market in 2007-2008, scholars have renewed interest in executive compensation levels and shifted their research focus from the non-financial industry to the financial industry (Guo et al., 2015). Executive compensation is the compensation plan given to the Chief Executive Officers (CEO) and other senior executives who are responsible for managing corporate affairs (Omoregie and Kelikume, 2017). In previous studies, there were different perspective 
about the impact of executive compensation on the banking performance. The alignment theory believes that giving incentives to the bank's executives could help the manager and the owner's goals to be aligned, which would reduce agency costs and promote managers to create maximum value for shareholders (Omoregie and Kelikume, 2017). However, the entrenchment theory states that higher compensation might lead the executives not paying attention to the development of the bank, but only seeking smooth performance, which would harm the interests of banks. Malmi and Ikäheimo (2003) pointed out that the EVA evaluation system is not only an evaluation method but also a comprehensive management mechanism. Establishing an incentive mechanism around EVA could maximize the coordination between managers and shareholders. Therefore, combining theoretical analysis with evidence from existing literature, the seventh hypothesis is as follows.

Hypothesis 7: There is a significantly positive relationship between the executive compensation and the bank's EVA.

\subsection{Board Size}

The board is the intermediate coordination mechanism between shareholders and managers, which need to accept the trust from the shareholders to manage the company as well as supervise and motivate managers (Fernandes et al, 2018). According to the theory of resource dependence, the increase in the number of directors means the increase in the resources available to the board of directors, which has the positive influence on the company's performance (Mohammed et al., 2017; Tulun and Ramdani, 2018). However, as the size of the board of directors expands, the agency problem becomes more and more prominent. When the number of board members exceeds the optimal range, the more time it takes for the coordination of the board members to ask, and the negative effect of the communication would exceed its positive effect (Fernandes et al., 2018). Mariappan and Thyagarajan (2018) found that board size was significantly related to performance when board size was between 6 and 9. Due to the large size of the board of Chinese banking companies, the difficulty of internal coordination increases, and the decision-making efficiency becomes lower. Therefore, the eighth hypothesis is as follows. 
Hypothesis 8: There is a significantly negative relationship between board size and the bank's EVA.

\subsection{Proportion of independent directors}

Independent directors refer to committee members who are not associated with directors, other committee members and controlling shareholders (Fernandes et al, 2018). Due to the 'independence' of independent directors, the increase in the proportion of independent directors could effectively supervise the behaviour of ordinary directors. Independent directors would attempt to protect the interests of minority shareholders and stakeholders, which is conducive to the company's long-term sustainable development (Tulun and Ramdani, 2018). In addition, they often have high professional knowledge or professional experience when they are appointed, which could also have a positive impact on the business performance of commercial banks (Fernandes et al, 2018). Tulun and Ramdani (2018) and Mariappan and Thyagarajan (2018) found the significant positive correlation between the proportion of independent directors and the bank's performance. Therefore, the ninth hypothesis is as follows.

Hypothesis 9: There is a significantly positive relationship between proportion of independent directors and the bank's EVA.

\section{Data and Method}

\subsection{Sample selection}

This study sample consists of listed banks in China, for the period starts in 2012 and ends in 2017. The initial sample consists of 17 banks, as listed in year-end 2012.We exclude the Chongqing Rural Commercial Bank (CQRCB) due to the inconsistency in currency measurement and accounting standards. Therefore, the final sample includes the data for the six years of the 16 banks in China that are listed on the Shanghai Stock Exchange and Shenzhen Stock Exchange, which totalled 96 firm year observation. The specific name, abbreviation, stock code and classification of samples are shown in Appendix 1. And the data sources of this paper are the FitchConnect, CSMAR databases and annual reports of each bank. 


\subsection{Dependent variables}

The purpose of this paper is to study the determinants of Economic Value Added (EVA) in Chinese Listed Banks. However, the EVA is an absolute indicator and is related to the size of the enterprise, which means the larger size of the general enterprise would produce the larger EVA value. Therefore, this paper would normalize the EVA by using the economic value added rate of return (REVA), which divides the EVA by the total capital.

As the two traditional indicators to measure the profitability of banks, Return on Assets (ROA) and Return on Equity (ROE) are used (Heffernan and Fu, 2010; Bennaceur and Goaied 2008; Sufian and Chong 2008; Sufian 2009; Heffernan and Fu 2010; Ali et al., 2011). Specifically, ROA is the ratio of the net income of a bank to the total assets, which refers to the ability to use entire funds to obtain profits (Bennaceur and Goaied 2008; Sufian and Chong 2008; Sufian 2009; Heffernan and Fu 2010, Ali et al., 2011, Aladwan 2015 ; Petria et al., 2015). ROE is an important indicator that shareholders usually consider and is directly related to shareholder wealth, reflecting the return on investment of banks. This indicator has a positive relation with the profitability of banks. The larger the value, the stronger the profitability of banks' capital. Therefore, this paper will use REVA, ROA and ROE as the dependent variables.

\subsection{Independent variables}

According to the nine hypotheses proposed in Section 3 on the determinants of EVA, nine corresponding independent variables will be proposed.

- LNTA: the natural logarithm of total assets, which is a measure of bank size. Because its large value might cause heteroscedasticity, it would be adjusted by natural logarithm. According to Hypothesis 1, the higher the LNTA, the higher the EVA.

- LOAN/TA: measures the liquidity of banks, which is the ratio of total loans divided by total assets. According to Hypothesis 2, the higher the LOAN/TA, the lower the EVA.

- LLR: implies how much provision prepared for the loan loss compared with the total loan, which shows the credit risk of banks. Based on Hypothesis 3, a negative 
relationship with EVA is expected.

- $\mathrm{C} / \mathrm{B}$ : cost to income ratio, which revealed the operational efficiency of the bank. According to Hypothesis 4, the higher C/B implies lower operational efficiency and EVA.

- CAR: capital adequacy ratio, that is, ratio of equity capital to total assets (Bennaceur and Goaied, 2008; Heffernan and Fu, 2010; Ali et al, 2011; Petria et al, 2015). According to Hypothesis 5, CAR has a negative relationship with EVA.

- NIIR: measure the level of innovation in a bank, which is the ratio of non-interest income to operating income. As Hypothesis 6 shows, the higher NIIR could produce higher EVA.

- EC: is executive compensation and it is an important part of corporate governance. This paper will use the average of the top three executive compensation represent executive compensation. Due to its large value, it would be adjusted by natural logarithm. Based on Hypothesis 7, the high EC would have positive affect on EVA.

- BODS: the number of executives sits on board including the board of commissioners and board of directors, which is a measure of board size. According to Hypothesis 8, the larger size of board would cause lower EVA.

- IND: the proportion of independent directors in the board. According to Hypothesis 9, the higher IND implies higher independence of the board, which would have positive influence on EVA.

\subsection{Empirical Research Model}

Our research models are designed with REVA, ROA, ROE as dependent variables and LNTA, LOAN/TA, LLR, C/B, CAR, NIIR, EC, BODS and IND as independent variables. The formula of the empirical research model is shown as follows:

$R E V A / R O A / R O E=\beta_{0}+\beta_{1} L N T A+\beta_{2} L O A N / T A+\beta_{3} L L R+\beta_{4} C / B+\beta_{5} C A R+\beta_{6} N I I R$ $+\beta_{7} E C+\beta_{8} B O D S+\beta_{9} I N D+\varepsilon$

Where $\beta_{0}$ a constant term, $\beta_{1,} \beta_{2,} \beta_{3,} \beta_{4}, \beta_{5}, \beta_{6}, \beta_{7}, \beta_{8}$ and $\beta_{9}$ are the regression coefficients of the variable and $\varepsilon$ is the residual term of the regression equation.

\subsection{Descriptive and correlation analysis}


As reported in Table 2, the average value of REVA is $12.52 \%$, which indicates the overall return rate of economic value added is high. The maximum value of REVA is $21.20 \%$ of CMBC in 2012, and the minimum value of that is $3.57 \%$ of PAB in 2013 . This shows that the gap between the value creation capabilities of the 16 sample banks is wide. The traditional performance evaluation indicators ROE shows the similar gap to REVA, while the ROA of each bank is not much different.

Among the independent variables, the standard deviation of LNTA is large, which indicated that the scale of assets of China's listed banks is very different, especially the five major state-owned banks who occupy an absolute advantage. On the other hand, the standard deviation of LLR and CAR is relatively small, which means the credit risk and capital management of the 16 listed banks are not much different and the overall level is balanced. This is mainly because the related laws and regulations have some restrictions on credit risk and capital adequacy ratio to protect the normal operation of the banking industry. In addition, the average value of LOAN/TA is $47.69 \%$, indicating that the liquidity of the Chinese banking industry is good. However, the average value of $\mathrm{C} / \mathrm{B}$ is $72.86 \%$ and it represents that the cost to income ratio is high, which may cause the inefficiency of bank's operating. The average value of NIIR is $22.64 \%$ and is increasing by the year, which could imply that with the emergence of new financial companies and alternatives, China's banks are increasingly focusing on their own innovation capabilities to enhance competitiveness.

In terms of corporate governance, Table 2 shows that the standard deviation of executive compensation is high, the minimum of which is ICBC in 2016 with the top three executives' per capita salary is 546,633 yuan while the maximum is from PAB in 2014 reached 752,310 yuan. However, the board size of each bank is relatively reasonable, and the average proportion of its independent directors in the board accounted for $36.84 \%$, with a standard deviation of 0.0433 . This reflects that the internal control system of China's listed banks is relatively sound, which could effectively improve corporate governance capabilities and play a deterrent role in accounting fraud and other acts that undermine the market economy. 


\begin{tabular}{cccccc}
\hline Variables & $\mathrm{N}$ & Minimum & Maximum & Mean & Std. Deviation \\
\hline REVA & 96 & 0.0351 & 0.2120 & 0.1252 & 0.0322 \\
ROA & 96 & 0.0074 & 0.0147 & 0.0109 & 0.0018 \\
ROE & 96 & 0.1076 & 0.2531 & 0.1703 & 0.0336 \\
LNTA & 96 & 26.5633 & 30.8925 & 29.0879 & 1.0827 \\
LOANTA & 96 & 0.3048 & 0.5832 & 0.4769 & 0.0730 \\
LLR & 96 & 0.0174 & 0.0453 & 0.0273 & 0.0063 \\
CB & 96 & 0.5252 & 1.0471 & 0.7286 & 0.1330 \\
CAR & 96 & 0.0502 & 0.0821 & 0.0657 & 0.0080 \\
NIIR & 96 & 0.1002 & 0.3747 & 0.2264 & 0.0661 \\
EC & 96 & 13.2115 & 15.8335 & 14.3749 & 0.6239 \\
BODS & 96 & 2.0794 & 2.9957 & 2.7127 & 0.1634 \\
IND & 96 & 0.2500 & 0.5000 & 0.3684 & 0.0433
\end{tabular}

*Variable definitions: see section 4.3

The purpose of the correlation analysis of explanatory variables is to check for the multicollinearity between variables and make initial testing of the main hypotheses. Table 3 report the Pearson correlation between all variables. 
Table 3 Pearson correlation coefficient analysis

\begin{tabular}{llllllllll}
\hline & LNTA & LOAN/TA & LLR & C/B & CAR & NIIR & EC & BODS IND \\
\hline LNTA & 1 & & & & & & & & \\
LOAN/TA & 0.684 & 1 & & & & & & & \\
LLR & 0.026 & -0.282 & 1 & & & & & & \\
C/B & 0.12 & 0.083 & 0.107 & 1 & & & & & \\
CAR & 0.596 & 0.586 & -0.127 & 0.193 & 1 & & & & \\
NIIR & 0.477 & 0.32 & -0.107 & 0.793 & 0.474 & 1 & & & \\
EC & -0.406 & -0.128 & -0.285 & 0.299 & -0.41 & 0.071 & 1 & & \\
BODS & -0.084 & 0.085 & -0.188 & -0.083 & -0.115 & 0.038 & 0.122 & 1 & \\
IND & 0.032 & 0.132 & -0.145 & -0.024 & 0.062 & -0.024 & 0.021 & -0.279 & 1 \\
\hline
\end{tabular}

*Variable definitions: see section 4.3

From the correlation coefficient between the variables in Table 4.3, except that the correlation coefficient between $\mathrm{C} / \mathrm{B}$ and NIIR is 0.793 which indicates that the correlation between these two is high, the correlation between other variables is not very strong. This means that the multicollinearity problem does not occur between the variables selected in this paper.

\subsection{Main analysis and discussion.}

To test our research hypotheses, this paper uses a multiple linear regression model to analyze the factors affecting the REVA value of China's listed banks. We also use return on equity (ROE) and return on assets (ROA) as robustness proxies of EVA. The regression results are shown in Table 4. 
Table 4: The regression results of the determinants of REVA, ROE and ROA

\begin{tabular}{|c|c|c|c|}
\hline VARIABLES & REVA & ROE & ROA \\
\hline \multirow[t]{2}{*}{ LNTA } & 0.00844 & $0.00722 * *$ & $0.000473^{* *}$ \\
\hline & [1.646] & [2.169] & [2.161] \\
\hline \multirow[t]{2}{*}{ LOAN/TA } & -0.0131 & 0.0176 & -0.0000918 \\
\hline & {$[-0.197]$} & [0.409] & {$[-0.0324]$} \\
\hline \multirow[t]{2}{*}{ LLR } & $0.347 * * *$ & 0.476 & 0.0252 \\
\hline & [2.993] & [1.254] & [1.011] \\
\hline \multirow[t]{2}{*}{$\mathrm{C} / \mathrm{B}$} & $-0.161 * * *$ & $-0.263 * * *$ & $-0.0161 * * *$ \\
\hline & {$[-3.287]$} & {$[-8.275]$} & {$[-7.691]$} \\
\hline \multirow[t]{2}{*}{ CAR } & $-1.857 * * *$ & $-2.244 * * *$ & 0.00971 \\
\hline & {$[-3.378]$} & {$[-6.292]$} & [0.414] \\
\hline \multirow[t]{2}{*}{ NIIR } & $0.245^{* *}$ & $0.233 * * *$ & $0.0136^{* * *}$ \\
\hline & {$[2.221]$} & [3.257] & [2.878] \\
\hline \multirow[t]{2}{*}{$\mathrm{EC}$} & 0.00887 & $0.0206^{* * *}$ & $0.00125^{* * *}$ \\
\hline & [1.379] & [4.939] & [4.556] \\
\hline \multirow[t]{2}{*}{ BODS } & -0.00821 & 0.00358 & -0.000238 \\
\hline & {$[-0.415]$} & [0.279] & {$[-0.0282]$} \\
\hline \multirow[t]{2}{*}{ IND } & -0.0957 & -0.0562 & -0.0019 \\
\hline & {$[-1.392]$} & {$[-1.260]$} & {$[-0.646]$} \\
\hline \multirow[t]{2}{*}{ Constant } & -0.0483 & -0.0604 & -0.0127 \\
\hline & {$[-0.233]$} & {$[-0.449]$} & {$[-1.439]$} \\
\hline Observations & 96 & 96 & 96 \\
\hline R-squared & 0.368 & 0.756 & 0.627 \\
\hline
\end{tabular}

*Variable definitions: see section 4.3

As reported in table 4, the explanatory power of the model is good, as its F statistic is significant at the level of $1 \%$ and the R-squared of this model is $36.80 \%{ }^{1}$ Our findings

\footnotetext{
1 We added some macro-factors to control the influence of environments. We added Inflation (INF), annual real GDP growth rate (GDPG) and annual unemployment rate (UNEMP). The findings as expected and consistent with prior studies (i.e. Heffernan \& Fu 2010) suggesting that bank performance appears to improve in an environment of falling employment and rising GDP growth rates. The findings are un-tabulated analysis.
} 
indicate that the credit risk (LLR), has a significance coefficient with a value of 0.347 , which indicates that for every $1 \%$ increase in the ratio of loan loss provision to total loan, the bank's REVA value will increase by $0.347 \%$. The LLR is positively related with EVA, which is against our expectation in hypothesis 3. However, this result is consistent with the findings of Sufian (2009), Heffernan and Fu (2010) and Sun et al (2017). There are two possible explanations for this result. The first is based on the assumptions of Berger and DeYoung (1997) that banks reasonably reduce short-term costs, including the provision of loan loss, to maximize long-term profits (Sufian, 2009). The second possible reason is that banks have different attitudes toward risk. Although the greater the risk, the greater the profit, it may also bring greater losses. Therefore, banks that are more cautious will increase their provision of loan loss, which shows the bank's cautiousness and timeliness in estimating its non-performing loans.

The findings also suggest that the impact coefficient of C/B on REVA is -0.161 , which means that every one-percentage point reduction in C/B will increase the bank's REVA by 0.161 percentage points. The lower the $\mathrm{C} / \mathrm{B}$, the higher the banks operational efficiency and the EVA value, which confirms Hypothesis 4. This result is consistent with most previous studies, in which Sufian (2009), Heffernan and Fu (2010) and Petra et al. (2015) documented that high operational efficiency contributes to the improvement of banking performance.

As predicted by hypothesis 5, capital management has a negative relation with the EVA value of China's banks. The capital adequacy ratio (CAR) which represents capital management is significant at the $1 \%$ level. In general, as the capital adequacy ratio increases, the bank's ability to resist risks increases. However, this also increases the financing cost of banks, and the fewer funds the banks use to issue loans. For banks that based on deposit and loan spread income, higher capital adequacy ratios would affect the bank's operating efficiency, causing the reduction in EVA indicators. These findings are consistent with prior study (Heffernan and Fu 2010; Petria et al. 2015; Ali et al. 2011). In addition, the EVA indicator itself would be constrained by the cost of capital. The increase in the bank's capital adequacy ratio would lead to the expansion of capital scale and the increase of capital cost. Therefore, how to balance the relationship between risk control and investment profit with the optimization of bank 
capital structure to achieve the goal of maximizing corporate value is further explored.

Moreover, the non-interest income ratio (NIIR) is positive and significant at the $5 \%$ significant level. This is in line with Sufian and Chong (2008) and the assumptions of Hypothesis 6 for financial innovation. Nowadays, the bank's profit mainly comes from the spread of income between deposits and loans. However, the business requires the bank to pay a certain capital cost to realize the income. The intermediate business does not have this problem, which is similar to the "non-cost business" comparing with the bank's traditional deposit and loan business (Sufian and Chong, 2008). Therefore, focusing on resources to expand the intermediary business is conducive to optimizing the bank's income structure and reducing the bank's credit risk, thereby enhancing the bank's profitability.

Besides the above four factors affecting EVA, bank Size (LNTA), liquidity (LOAN/TA), executive compensation (EC), board size (BODS) and proportion of independent directors (IND) are not significant. In particular, although some studies suggest that companies with larger board size would achieve greater performance (Tulun and Ramdani, 2018), and others such as Tulun and Ramdani (2018) had reached the opposite conclusion. Mariappan and Thyagarajan (2018) find that the size of the board and the company's performance are inversely U-shaped, and the best board size is 6 to 9 people. Thus, as a further analysis we separated the sample into three groups: banks with less than 13 member, banks with 13 -16 members, and above 16 members. Then, we re-estimate our baseline model. The findings, as reported in Table 5, suggest a negative relationship between board size and performance if the board size above 16 . This implies that the number of members of the board cannot reflect the efficiency of the board's operations. For the effectiveness of bank board governance, the number of members is not the key. Only by establishing a sound operation mechanism of the board can it be truly effective. This also suggest that as the size of the board of directors expands, the agency problem becomes more prominent and the coordination and communication between the board members become more difficult, then the negative effect of the communication would exceed its positive effect (Fernandes et al, 2018). 
Moreover, the proportion of independent directors (INDIA) is also not related to the three performance evaluation indicators selected in this paper, which indicates that the independence of board members has no significant impact on the performance of China's listed banks. This is contrary to the research by scholars such as Tulun and Ramdani (2018) and Mariappan and Thyagarajan (2018). In conclusion, it might be due to the weak corporate governance of the Chinese banking industry as a whole.

Table 5: The regression results of the determinants of REVA using sub-samples based on board size

\begin{tabular}{|c|c|c|c|}
\hline Variables & $(\mathrm{BODS}<13)$ & (BODS between 13 and 16 ) & $(\mathrm{BODS}<16)$ \\
\hline \multirow[t]{2}{*}{ LNTA } & $0.0183 * *$ & 0.0462 & 0.00933 \\
\hline & {$[2.658]$} & {$[0.738]$} & [1.632] \\
\hline \multirow[t]{2}{*}{ LOAN/TA } & -0.0135 & -0.903 & 0.0854 \\
\hline & {$[-0.0778]$} & {$[-1.150]$} & [1.061] \\
\hline \multirow[t]{2}{*}{ LLR } & $6.597 * *$ & 2.36 & 0.274 \\
\hline & [2.681] & {$[0.357]$} & {$[0.374]$} \\
\hline \multirow[t]{2}{*}{$\mathrm{C} / \mathrm{B}$} & $-0.136^{* *}$ & -0.258 & 0.0118 \\
\hline & {$[-2.454]$} & {$[-0.706]$} & {$[0.346]$} \\
\hline \multirow[t]{2}{*}{ CAR } & $-2.017^{*}$ & -3.44 & $-1.814 * * *$ \\
\hline & {$[-1.765]$} & {$[-0.859]$} & {$[-2.752]$} \\
\hline \multirow[t]{2}{*}{$\mathrm{EC}$} & -0.0072 & 0.00237 & $0.0244 * * *$ \\
\hline & {$[-0.583]$} & {$[0.0574]$} & [3.187] \\
\hline \multirow[t]{2}{*}{ BODS } & -0.00966 & -0.493 & $-0.0927 * *$ \\
\hline & {$[-0.386]$} & {$[-1.767]$} & {$[-2.173]$} \\
\hline \multirow[t]{2}{*}{ IND } & -0.108 & 0.00866 & -0.135 \\
\hline & {$[-1.508]$} & {$[0.0201]$} & [-1.189] \\
\hline \multirow[t]{2}{*}{ Constant } & -0.166 & 0.899 & -0.125 \\
\hline & {$[-0.616]$} & {$[0.514]$} & {$[-0.503]$} \\
\hline Observations & 32 & 13 & 51 \\
\hline R-squared & 0.747 & 0.75 & 0.476 \\
\hline
\end{tabular}

*Variable definitions: see section 4.3 
As a robustness proxies of REVA, this paper use two traditional performance evaluation indicators (ROE and ROA). Using ROA and ROE, the regression results are shown in Table 4. The findings of ROE and ROA mostly are consistent with the findings of REVA. For bank size, the expansion of the bank size will generally bring certain economies of scale. As reported in Table 4, under the ROA and ROE models, LNTA is significant at the $5 \%$ level. However, consistent with the results of the recent studies, this paper find that there the relationship between REVA and LNTA is not significant (Bennaceur and Goaied, 2008; Heffernan and Fu, 2010; Ali et al, 2011; Petria et al, 2015). This implies that it is no longer advisable to increase bank performance by blindly expanding the scale of assets. Likewise, it is unrealistic to rely solely on the increase in the number of loans to increase REVA (Heffernan and Fu, 2010). However, instead, our findings suggesting that improving bank performance by increasing financial innovation is the direction of future bank development.

Consistent with EVA findings, the two factors of bank corporate governance (board size and board independence), are not significant, which against our expectations in Hypothesis 8 and 9. However, we report that EC is significant at the $1 \%$ level in the models with ROA and ROE as the dependent variables. In general, the increase in the average salary of bank executives is beneficial to alleviate agency problem and thus obtain more profit (Omoregie and Kelikume, 2017; Malmi and Ikäheimo 2003). However, the regression results of REVA in this paper show that executive compensation cannot be increased indefinitely, and banks could adopt other methods such as equity incentives to improve the enthusiasm of managers.

\section{Conclusions and limitations}

The main purpose of this paper is to study the determinants of the EVA model in the Chinese banking industry. To achieve the goal, this paper uses the banks listed on the Shanghai and Shenzhen Stock Exchanges in 2012-2017 as samples and the EVA model was used to evaluate the operating performance of banks. Our empirical results suggest that the decisive factors affecting the EVA value of China's listed banks are credit risk (LLR), operational efficiency (C/B), capital management (CAR) and the degree of innovation (NIIR). Except for the above four factors, the other five factors did not have significant impact on REVA. However, it is worth noting that bank executive 
compensation is positively related to ROA and ROE.

Thus, our findings suggest that improving the operation efficiency and the degree of innovation, ensuring a certain level of credit risk and controlling a certain level of capital adequacy ratio could help improve the bank's operating performance. Developing diversified intermediary businesses and accelerating the pace of financial innovation is the future direction for the bank's development. Besides, the Chinese banks should also pay attention to optimize their corporate governance, especially the salary incentive mechanism.

This paper has some limitations. Firstly, due to a large number of adjustments to accounting items are required in the application of EVA when evaluating business performance, some items of EVA model in this paper have been simplified, which may cause the bank's EVA value to deviate slightly from the actual situation. Moreover, the sample includes only listed banks, so our results cannot generalized to non-listed banks, such as some small and medium-sized commercial banks. Therefore, in the future's research, the calculation of EVA could be more precise and the sample size of China's banks could be expanded. Furthermore, the impact of macro factors on banks' EVA could be appropriately considered when studying the determinants. Finally, our study employs individual elements of corporate governance. Future research can use composited measure of corporate governances such as G-score. 


\section{References}

Aladwan, M. S. (2015). The Impact of Bank Size on Profitability "An Empirical Study on Listed Jordanian Commercial Banks". European Scientific Journal, ESJ, 11(34).

Ali, K., Akhtar, M. F. and Ahmed, H. Z. (2011) Bank-Specific and Macroeconomic Indicators of Profitability - Empirical Evidence from the Commercial Banks of Pakistan. International Journal of Business and Social Science, 2(6), 235-242.

Mamun, A. A., Entebang, H. and Mansor, S. A. (2012) EVA as superior performance measurement tool. Modern Economy, 3(03), 310-318.

Bennaceur, S. and Goaied, M. (2008) The Determinants of Commercial Bank Interest Margin and Profitability: Evidence from Tunisia, Frontiers In Finance And Economics, 5(1), 106-130.

Burkert, M., Lueg, R., 2013. Differences in the sophistication of Value-based Management -The role of top executives. Manage. Account. Res. 24 (1), 3-22.

CBRC. (2016) 2015 Annual Report. Available from: http://www.cbrc.gov.cn/chinese/files/2016/6C1DEC063D6442B289B7C24F662D2E5 2.pdf [Accessed 28 August 2018].

Chiwamit, P., Modell, S., Yang, C., 2014. The societal relevance of management accounting innovations: economic Value Added and institutional work in the fields of Chinese and Thai state-owned enterprises. Account. Bus. Res. 44 (2),144-180.

Chiwamit, P., Modell, S., \& Scapens, R. W. (2017). Regulation and adaptation of management accounting innovations: The case of economic value added in Thai stateowned enterprises. Management Accounting Research, 37, 30-48.

EY (2013) Listed banks in China: 2012 review and outlook. Available from: https://www.ey.com/cn/en/industries/financial-services/banking---capitalmarkets/2012-review-of-china-listed-banks-and-outlook [Accessed 28 August 2018]. 
EY (2017) Listed banks in China: 2017 review and outlook. Available from: https://www.ey.com/Publication/vwLUAssets/ey-china-listed-banking-report-2017en/\$FILE/ey-china-listed-banking-report-2017-en.pdf [Accessed 28 August 2018].

Fernandes, C., Farinha, J., Martins, F. V. and Mateus, C. (2018) Bank governance and performance: a survey of the literature. Journal of Banking Regulation, 19(3), 236-256.

Fraker, G. T. (2006) Using Economic Value Added (EVA) to Measure and Improve Bank Perfromance. RMA-Arizona Chapter. Available from: http://www.rmaaz.org/pictures/measuringbankperformance.pdf [Accessed 28 August 2018].

Franco, F. and Philip, M. (2007) Value Creation in Banking. Paper presented at EFA 2007 Ljubljana Meetings, Ljubljana, February 2007.

Gabriela, P., Laurentiu, M.and \& Codin, C. (2009) EVA-Advanced method for performance evaluation in banks. Economia. Seria Management, 12(1 Special), 168173.

Guo, L., Jalal, A. and Khaksari, S. (2015) Bank Executive Compensation Structure, Risk Taking and the Financial Crisis, Review of Quantitative Finance and Accounting, 45(3), 609-639.

Heffernan, S. and Fu, X. (2010) Determinants of Financial Performance in Chinese Banking, Applied Financial Economics, 20(19-21), 1585-1600.

Jakub, S., Viera, B. and Eva, K. (2015) Economic Value Added as a Measurement Tool of Financial Performance. Procedia Economics and Finance, 26, 484-489.

Kennedy, P. (2003) A guide to econometrics. MIT press.

Li, T. and Guan, C. (2009) Study on the Behaviors of Commercial Banks Based on Bank Particularities. International Journal of Business and Management, 3(7), 113. 
Malmi, T. and Ikäheimo, S. (2003) Value Based Management practices-some evidence from the field, Management Accounting Research, 14, 235-254.

McLaren, J., Appleyard, T., Mitchell, F., 2016. The rise and fall of management accounting systems: a case study investigation of EVATM. Br. Account. Rev. 48(3), $341-358$.

Mariappan. V. and Thyagarajan. S. (2018) Board characteristics and bank performance in India, IIMB Management Review.

Mohammed, N. F., Ahmed, K., \& Ji, X. D. (2017). Accounting conservatism, corporate governance and political connections. Asian Review of Accounting, 25(2), 288-318.

Omoregie, O. and Kelikume, I. (2017) Executive Compensation and Banking Sector Performance: Evidence from Nigeria. Journal of Developing Areas, 51(2), 1-15.

Petria, N., Capraru, B. and Ihnatov, I. (2015) Determinants of banks' profitability: evidence from EU 27 banking systems. Procedia Economics and Finance, 20, 518-524.

PWC (2015) Banking and finance in China: The outlook for 2015. Available from: csf.kiep.go.kr/file/download.do?fileId=3545 [Accessed 28 August 2018].

Sabol, A. and Sverer, F. (2017) A Review of the Economic Value Added Literature and Application. UTMS Journal of Economics, 8(1), 19-27.

Sharma, A, K. and Kumar, S. (2010) Economic value added (EVA)-literature review and relevant issues. International Journal of Economics and Finance, 2(2), 200.

Shreenivasan. K. A. and Vaijayanthi. (2011) Value based measure: An application of EVA in selected Indian public and private banks. In Business, Engineering and Industrial Applications (ICBEIA), 2011 International Conference on (pp. 41-46). IEEE.

Soral, G. and Bhanawat, S. (2009) Shareholder Value Creation in the Indian Banking 
Industry: An EVA Analysis. IUP Journal of Accounting Research \& Audit Practices, $8(3 / 4), 52-60$.

Stewart, B. (2009) EVA momentum: The one ratio that tells the whole story. Journal of Applied Corporate Finance, 21(2), 74-86.

Stewart, G. B. (1991) The Quest for Value. New York: Harper Collins Publishers, pp 224.

Sufian, F. (2009) Determinants of bank profitability in a developing economy: Empirical evidence from the china banking sector. Journal of Asia-Pacific Business, 10(4), 281-307.

Sufian, F. and Chong, R. R. (2008) Determinants of Bank Profitability in A Developing Economy: Empirical Evidence from The Philippines. Asian Academy of Management Journal of Accounting and Finance, 4(2), 91-112.

Sun, P. H., Mohamad, S. and Ariff, M. (2017) Determinants driving bank performance: A comparison of two types of banks in the OIC. Pacific-Basin Finance Journal, 42, 193 203.

Tulung, J. E. and Ramdani, D. (2018) Independence, Size and Performance of the Board: An Emerging Market Research. Corporate Ownership \& Control, 15(2).

Worthington, A. C., \& West, T. (2001). Economic value-added: A review of the theoretical and empirical literature. Asian Review of Accounting, 9(1), 67-86.

Uyemura, D. G., Kantor, C. C. and Pettit, J. M. (1996) EVA for Banks: Value Creation, Risk Management, and Profitability Measurement. Journal of Applied Corporate Finance, 9(2), 94. 


\section{Appendix A}

Table 116 Listed Banks of China in 2012

\begin{tabular}{lll}
\hline Five large commercial banks & Stock Code \\
\hline 1 & Industrial and Commercial Bank of China (ICBC) & 601398 \\
2 & China Construction Bank (CCB) & 601939 \\
3 & Agricultural Bank of China (ABC) & 601288 \\
4 & Bank of China (BOC) & 601988 \\
5 & Bank of Communications (BOCOM) & 601328 \\
Eight & \\
6 & Chational joint stock commercial banks & 600036 \\
7 & China Minsheng Bank (CMBC) & 600016 \\
8 & Industrial Bank (IB) & 601166 \\
9 & Shanghai Pudong Development Bank (SPDB) & 600000 \\
10 & China CITIC Bank (CITIC) & 601998 \\
11 & China Everbright Bank (CEB) & 601818 \\
12 & Huaxia Bank (HX) & 600015 \\
13 & Ping An Bank (PAB) & 000001 \\
Three city commercial banks & \\
14 & Bank of Beijing (BOB) & 601169 \\
15 & Bank of Ningbo (BONB) & 002142 \\
16 & Bank of Nanjing (BONJ) & 601009 \\
\hline \multicolumn{2}{c}{ Source: Listed banks in China 2012 review and outlook (EY, 2013) }
\end{tabular}




\section{Appendix B}

\section{Description of Variables}

\begin{tabular}{|c|c|c|}
\hline Dependent Variables & & Description \\
\hline REVA & & EVA/Total Capital \\
\hline ROA & & Net Income/Average Assets \\
\hline ROE & & Net Income/Average Equity \\
\hline Independent variables & Determinants & Description \\
\hline LNTA & Bank Size & Natural logarithm of total assets \\
\hline LOAN/TA & Liquidity & Total loans/Total assets \\
\hline LLR & Credit Risk & Loan loss provision/Total loan \\
\hline $\mathrm{C} / \mathrm{B}$ & Operational Efficiency & Total operating expenses/net-Interest income \\
\hline CAR & Capital Management & Equity capital/Total assets \\
\hline NIIR & Degree of innovation & Non-interest income/Operating income \\
\hline $\mathrm{EC}$ & Executive compensation & The natural logarithm of the average of the top three executive compensation \\
\hline BODS & Board Size & $\begin{array}{c}\text { The number of executives sits on board including the board of commissioners and } \\
\text { board of directors. }\end{array}$ \\
\hline IND & $\begin{array}{l}\text { Proportion of } \\
\text { independent directors }\end{array}$ & The number of independent commissioners/ Total number of the board \\
\hline
\end{tabular}


